This is a postprint version of the following published document:

Limer, A. J., Rullay, A. K., Miguel, V. S., Peinado, C., Keely, S., Fitzpatrick, E., Carrington, S. D., Brayden, D. \& Haddleton, D. M. (2006). Fluorescently tagged star polymers by living radical polymerisation for mucoadhesion and bioadhesion. Reactive and Functional Polymers, 66 (1), pp. 51-64.

DOI: $10.1016 /$ j.reactfunctpolym.2005.07.024

(C) Elsevier, 2005

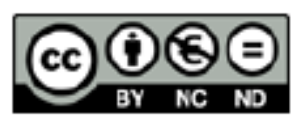

This work is licensed under a Creative Commons Attribution-NonCommercialNoDerivatives 4.0 International License. 


\title{
Fluorescently tagged star polymers by living radical polymerisation for mucoadhesion and bioadhesion
}

\author{
Adam J. Limer ${ }^{\text {a }}$, Atvinder K. Rullay ${ }^{\text {a, }}$, Veronica San Miguel ${ }^{\mathrm{b}}$, \\ Carmen Peinado ${ }^{\mathrm{b}}$, Simon Keely ${ }^{\mathrm{c}}$, Eamonn Fitzpatrick ${ }^{\mathrm{c}}$, \\ Stephen D. Carrington ${ }^{\mathrm{c}}$, David Brayden ${ }^{\mathrm{d}}$, David M. Haddleton ${ }^{\mathrm{a}, *}$ \\ a Department of Chemistry, University of Warwick, Coventry CV4 7AL, UK \\ ${ }^{\mathrm{b}}$ Instituto de Ciencia y Tecnologia de Polimeros, CSIC, Juan de la Cierva 3, 28006 Madrid, Spain \\ ${ }^{c}$ Department of Veterinary Anatomy, Faculty of Veterinary Medicine, University College Dublin, Dublin 4, Ireland \\ d Department of Small Animal Clinical Studies, Faculty of Veterinary Medicine, University College Dublin, Dublin 4, Ireland
}

\begin{abstract}
The synthesis of 3-, 5- and 8-arm dimethylaminoethyl methacrylate star polymers are reported, final $M_{\mathrm{n}}$ $(\mathrm{PDI})=12.2 \mathrm{~K}(1.09), 18.9 \mathrm{~K}(1.10)$ and $38.4 \mathrm{~K}(1.11)$, respectively. The synthesis of 3-arm methyl methacrylate and dimethylaminoethyl methacrylate block co-polymer stars is also described. Living polymerisation occurred in all cases providing well defined stars with predictable molecular weights and narrow polydispersity. A fluorescent tag, 2-(8-methacryloyloy-3,6-dioxaoctyl)thioxantheno[2,1,9-dej]isoquinoline-1,3-dione, derived from a commercially available pigment, was incorporated into the star polymers. The fluorescence spectra of the polymers prepared were recorded over a range of $\mathrm{pH}$ and the peak emission frequency and intensity have been reported, $\lambda_{\mathrm{ex}}=462 \mathrm{~nm}$. All of the multi-arm polymers exhibit fluorescence across a broad $\mathrm{pH}$ range with maximum emission at $\mathrm{pH}$ 4. A 3-arm star polymer has been demonstrated to show good bioadhesion in rat tissue. A reduced adhesion in epithelial tissues not covered by a viscoelastic mucus gel indicates an increased tendency for mucoadhesion over bioadhesion.
\end{abstract}

Keywords: ATRP; Living radical polymerisation; Mucoadhesion; Bioadhesion; Star polymers; Fluorescent polymer

\footnotetext{
* Corresponding author. Tel.: +44 2476 523256; fax: +44 2476528267.

E-mail address: d.m.haddleton@warwick.ac.uk (D.M. Haddleton).
}

\section{Introduction}

Star polymers exhibit interesting solution and solid state properties arising from their three dimensional shape [1]. These properties often derive from the differences in hydrodynamic volumes 
and higher degrees of chain end functionality compared to linear polymers of similar composition due to increased intermolecular constraints $[2,3]$. A variety of approaches has been reported for the synthesis of star polymers [4,5]. The first approach is the arms first method which uses living polymerisation to prepare the arms followed by quenching with a multi-functional coupling agent which serves as the core [6-9]. The second approach, often known as the nodule method, is also based on living polymerisation. Propagation is followed by cross-linking with divinyl reagents $[10-12]$. This approach is very limited and produces ill defined stars, however if the coupling termination at this point is minor it is possible to prepare miktoarm stars using the star polymer as an initiator [13]. The final approach is the core first method, which uses a multi-functional initiator to initiate living polymerisation and more specifically living radical polymerisation [14-17].

Transition metal mediated living radical polymerisation (LRP) (often called ATRP) has emerged as effective technique for the controlled polymerisation of styrenics, methacrylates, acrylates and acrylonitrile [18-21]. Living radical polymerisation is particularly suited to the synthesis of complex polymer architectures due to the relative simplicity of the procedure and wide array of monomers and initiators available [22]. There have been several publications which discuss the preparation of star polymers by transition metal mediated LRP. Matyjaszewski et al. have employed organic polyols, cyclotriphosphazines and cyclosiloxanes as multi-functional cores for the preparation of star polymers [2]. Sawamoto et al. and Gnanou et al. reported the use of modified calixarenes as multi-functional initiators to prepare styrenic and (meth)acrylic star polymers [5,23]. Hendrick et al. reported the preparation of amphiphilic star polymers that formed micelles in solution, [24] as well as the preparation of stars from dendritic cores [25]. Percec et al. reported the preparation of multi-arm star polymers with varying numbers of arms. These polymers were prepared using multi-sulfonyl chloride initiators [26]. Haddleton et al. have reported the preparation of star polymer using cores based on aromatic alcohols, [27] sugars [28] and cyclodextrin [22]
Gnanou and Matyjaszewski have also used branched alcohols to achieve similar effects $[29,30]$. Publications by Hawker et al., describe the use of nitroxide mediated polymerisations for the preparation of functionalised stars [31]. Publications by Moad and Rizzardo [32] as well as Davis et al. [33] describe the use of reverse addition fragmentation transfer polymerisation (RAFT) to synthesise star polymers.

As an interface between environment and organism, mucous membranes and epithelial structures are an important barrier against exogenous noxes e.g., microorganisms, toxins or physical and chemical irritations [34]. It is commonly accepted that damage to these membranes may have a negative effect on their protective function. This is particularly evident where irritations and inflammations of membranes from the gastrointestinal system occur. Clinical symptoms may range from sore throats to gastric diseases and to chronic inflammations with severe symptoms such as Colitis ulcerosa or Crohn's disease where significant injuries to the mucous membranes of the colon occur. A polymer that can adhere to mucus providing stabilization in areas where it is thin and weak could prevent the further loss of mucus and hence the exposure of delicate membranes to irritation and attack. Several investigations, which use hydrogels of crosslinked poly(arylic acid) or chitosan as mucoadhesives, have been carried out $[35,36]$. However the use of more advanced polymers has been less well studied. It is believed that polymers containing amine functionality and also glycopolymers may offer significant advancements in this area.

Materials containing fluorescent tags are useful as they may be observed using a fluorescence microscope. This is particularly beneficial when observing a material which is being delivered into a system as the location of the material can be observed and hence its effectiveness may be determined. These systems can be studied in even greater detail using laser scanning confocal microscopy [37].

At the outset of this work we hypothesized that multi-arm polymers might entangle with a substrate more than linear polymers would and as we had a family of multi-functional initiators to 
<smiles>CC(C)(Br)C(=O)Oc1cc(OC(=O)C(C)(C)Br)cc(OC(=O)C(C)(C)Br)c1</smiles><smiles>CC(C)(Br)C(=O)OC[C@@H]1CC(Br)(C(=O)OC(=O)C(C)(C)Br)C(OC(=O)C(C)(C)Br)[C@H](OC(=O)C(C)(C)Br)O1</smiles><smiles>CC(C)(Br)C(=O)OC[C@H]1O[C@H](O[C@@H]2[C@@H](COC(=O)C(C)(C)Br)O[C@H](OC(=O)C(C)(C)Br)[C@@H](OC(=O)C(C)(C)Br)[C@@H]2OC(=O)C(C)(C)Br)[C@H](OC(=O)C(C)(C)Br)[C@@H](OC(=O)C(C)(C)Br)[C@@H]1OC(=O)C(C)(C)Br</smiles><smiles>C=C(C)C(=O)OCCCCCn1c(=O)c2ccc3sc4ccccc4c4ccc(c1=O)c2c34</smiles>

Fig. 1. Reagents used in this work: (a) 1,3,5-tri- $O$-isobutyryl bromide benzene, (b) 1,2,3,4,6-Penta- $O$-isobutyryl bromide- $\alpha$-D-glucose, (c) 8-arm lactose initiator and (d) fluorescent monomer.

hand we started work with a range of 3-, 5- and 8arm fluorescent star polymers. Multi-functional initiators were prepared from 1,3,5-trihydroxybenzene, glucose and lactose as shown in Fig. 1. Copolymers of 2-(dimethylamino)ethyl methacrylate (DMAEMA) and a fluorescently tagged monomer derived from hostasol, a commercial dye, [38] have been synthesized using these multi-functional initiators. Scheme 1 outlines the approach used to prepare multi-arm DMAEMA and hostasol polymers.

\section{Experimental}

\subsection{Materials}

Methyl methacrylate (MMA) (Aldrich; 99\%) was purified by passage through a short column of activated basic alumina before use to remove inhibitors and acidic impurities. This was subsequently deoxygenated by bubbling with dry nitrogen gas for $30 \mathrm{~min}$ then stored at $0{ }^{\circ} \mathrm{C}$. 2-Dimethylaminoethyl methacrylate (DMAEMA) (Aldrich; 98\%)<smiles>CC(C)(Br)C(=O)Oc1cc(OC(=O)C(C)(C)Br)cc(OC(=O)C(C)(C)Br)c1</smiles><smiles>C=C(C)C(=O)OCCCCCn1c(=O)c2ccc3sc4ccccc4c4ccc(c1=O)c2c34</smiles>

Scheme 1. Preparation of Fluorescent 3-arm star polymer. 
was subjected to three freeze, pump and thaw cycles prior to use. Toluene (BDH, 98\%) was degassed by bubbling with nitrogen for $30 \mathrm{~min}$ and stored in a sealed flask under an atmosphere of nitrogen. Copper(I) bromide (Aldrich 99\%) was purified according to the method of Keller and Wycoff [39]. Hostasol (thioxantheno[2,1,9-dej]isochromene-1,3dione) was supplied by Clariant. All other materials were obtained from Aldrich and were used without any further purification unless otherwise stated.

\subsection{Characterisation}

${ }^{1} \mathrm{H}$ and ${ }^{13} \mathrm{C}$ NMR spectra were recorded on a Bruker DPX300 spectrometer using deuterated solvents from Aldrich. Size exclusion chromatography was carried out using a Polymer Laboratories modular system equipped with a differential refractive index (DRI) and UV/VIS detectors calibrated with linear poly(methyl methacrylate) standards $\left(M_{\mathrm{p}}=200\right.$ to $\left.1.577 \times 10^{6} \mathrm{~g} \mathrm{~mol}^{-1}\right)$ and linear poly(styrene $)$ standards $\left(M_{\mathrm{p}}=540\right.$ $\left.1.640 \times 10^{6} \mathrm{~g} \mathrm{~mol}^{-1}\right)$. The mobile phase used was 95\% THF, 5\% Triethylamine and the elution time was standardised against that of toluene. The flow rate was set at $1.0 \mathrm{~mL} / \mathrm{min}$. The system was equipped with a PL-gel $5 \mu \mathrm{m}(50 \times 7.5 \mathrm{~mm})$ guard column and two PL-gel $5 \mu \mathrm{m}(300 \times 7.5 \mathrm{~mm})$ mixed $\mathrm{C}$ columns, these were thermostated at $25^{\circ} \mathrm{C}$. Fluorescence measurements were conducted using a Perkin Elmer LS50B. The samples were excited at a frequency of $462 \mathrm{~nm}$ and the emission spectra was recorded between 300 and $700 \mathrm{~nm}$ at a scan rate of $200 \mathrm{~nm} \mathrm{~min}{ }^{-1}$.

\subsubsection{2-(8-Hydroxy-3,6-dioxaoctyl) thioxantheno} [2,1,9-dej]isoqiunoline-1,3-dione, $E$

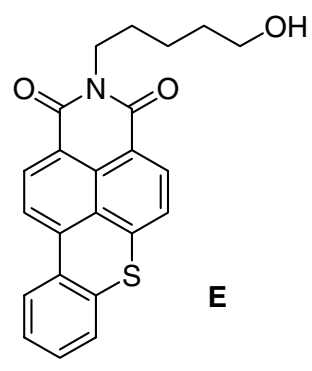

2-(8-Hydroxy-3,6-dioxaoctyl)thioxantheno[2,1,9dej]isoqiunoline-1,3-dione, $\mathbf{E},(10 \mathrm{~g}, 32.86 \mathrm{mmol})$ was suspended in anhydrous DMF $(60 \mathrm{~mL})$ under nitrogen at $25^{\circ} \mathrm{C}$. 5-Aminopentanol $(20.34 \mathrm{~g}$, $197.15 \mathrm{mmol}$ ) and $p$-toluenesulfonic acid monohydrate ( $p$ TSA) $(0.375 \mathrm{~g}, 1.971 \mathrm{mmol})$ were added. The reaction mixture was stirred at $130{ }^{\circ} \mathrm{C}$ under nitrogen and followed by TLC (toluene-methanol, $\left.4: 1(\mathrm{v} / \mathrm{v}), R_{f} 0.45\right)$. A further portion of $p$ TSA $(0.375 \mathrm{~g}, 1.971 \mathrm{mmol})$ and 5 -aminopentanol $(1 \mathrm{~g}$, $9.69 \mathrm{mmol}$ ) were added at $t=3 \mathrm{~h}$. After $6.5 \mathrm{~h}$, the reaction mixture was allowed to cool to $50{ }^{\circ} \mathrm{C}$ and methanol was added $(30 \mathrm{~mL})$. The resulting bright orange solid was filtered and washed with cold methanol $(3 \times 40 \mathrm{~mL})$. The solid was dried under vacuum at $80{ }^{\circ} \mathrm{C}$ to give alcohol $(11.83 \mathrm{~g}, 92 \%)$ as a bright orange solid. Mp 150 $152{ }^{\circ} \mathrm{C}$.

${ }^{1} \mathrm{H}$ NMR (400 MHz, $d^{6}$-DMSO) $\delta$ 1.30-1.38 (m, 2H, H-3), 1.43-1.51 (m, 2H, H-2), 1.52-1.62 $(\mathrm{m}, 2 \mathrm{H}, \mathrm{H}-4), 3.38-3.44(\mathrm{~m}, 2 \mathrm{H}), 3.87(\mathrm{t}, 2 \mathrm{H}$, $J=7.5 \mathrm{~Hz}), 4.37(\mathrm{t}, 1 \mathrm{H}, J=5.1 \mathrm{~Hz}, \mathrm{OH}), 7.27$ $7.33(\mathrm{~m}, 3 \mathrm{H}), 7.34-7.39(\mathrm{~m}, 1 \mathrm{H}), 7.95(\mathrm{~d}, 1 \mathrm{H}$, $J=7.8 \mathrm{~Hz}), 8.00(\mathrm{~d}, 1 \mathrm{H}, J=8.5 \mathrm{~Hz}), 8.05-8.10$ $(\mathrm{m}, 2 \mathrm{H}) \cdot{ }^{13} \mathrm{C}$ NMR $\left(100 \mathrm{MHz}, d^{6}\right.$-DMSO) $\delta 23.1$, $27.2,32.2,39.6,60.5,117.1,119.4,120.1,120.2$, $123.9, \quad 126.1(\times 2), \quad 126.8, \quad 127.6, \quad 129.0,129.7$, $130.1,130.3,131.5,135.3,139.1,162.0(\mathrm{C}=\mathrm{O})$, $162.5 \quad(\mathrm{C}=\mathrm{O})$. HRMS $\left(\mathrm{EI}^{+}\right)$calcd for $\mathrm{C}_{23} \mathrm{H}_{19} \mathrm{NO}_{3} \mathrm{~S}^{+}$: 389.1086 , found: 389.1079 .

\subsubsection{2-(8-Methacryloyloy-3,6-dioxaoctyl) thioxantheno[2,1,9-dej]isoquinoline-1,3-dione, $F$}

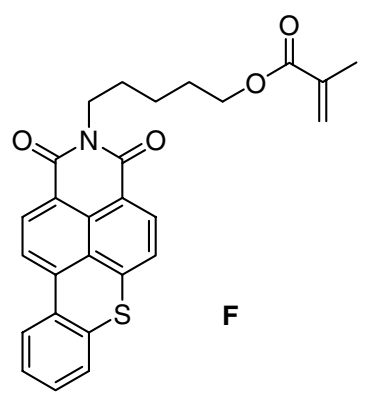

Anhydrous chloroform $(80 \mathrm{~mL})$ was added to a $250 \mathrm{~mL}$ round bottom flask containing alcohol 
( $2 \mathrm{~g}, 5.14 \mathrm{mmol})$ under an atmosphere of nitrogen at $25{ }^{\circ} \mathrm{C}$. Triethylamine $(3.6 \mathrm{~mL}, 26.09 \mathrm{mmol})$ was added and the reaction mixture cooled to $0^{\circ} \mathrm{C}$ (ice-bath). A solution of methacroyl chloride $(2.4 \mathrm{~mL}, 25.01 \mathrm{mmol})$ in anhydrous chloroform $(20 \mathrm{~mL})$ was added dropwise over a period of $1 \mathrm{~h}$. The reaction mixture was then left to stir at ambient temperature overnight and was followed by TLC (toluene-ethyl acetate, 5:1 (v/v). After $18 \mathrm{~h}$, the reaction mixture was cooled to $0{ }^{\circ} \mathrm{C}$ and methanol $(10 \mathrm{~mL})$ was added to destroy excess methacryloyl chloride and the mixture stirred for $1 \mathrm{~h}$ at ambient temperature. The reaction mixture was washed successively with saturated aqueous sodium chloride solution $(3 \times 100 \mathrm{~mL})$, saturated aqueous sodium hydrogen carbonate $(100 \mathrm{~mL})$, saturated aqueous sodium chloride solution $(100 \mathrm{~mL})$, dried over $\mathrm{MgSO}_{4}$, filtered and evaporated under reduced pressure to give an orange solid which was purified by silica chromatography (toluene-ethyl acetate, 5:1 (v/v)) and co-evaporating with methanol to give monomer, F $(2.07 \mathrm{~g}, 86 \%)$ as an orange solid. Mp 122$124{ }^{\circ} \mathrm{C}$.

${ }^{1} \mathrm{H}$ NMR $\left(400 \mathrm{MHz}, \mathrm{CDCl}_{3}\right) \delta 1.45-1.58(\mathrm{~m}$, $2 \mathrm{H}), 1.70-1.83(\mathrm{~m}, 4 \mathrm{H}), 1.92\left(\mathrm{~s}, 3 \mathrm{H}, \mathrm{CH}_{3}\right), 4.11-$ $4.19(\mathrm{~m}, 4 \mathrm{H}), 5.50-5.53(\mathrm{~m}, 1 \mathrm{H}), 6.06-6.10(\mathrm{~m}$, $1 \mathrm{H}), 7.26-7.37(\mathrm{~m}, 4 \mathrm{H}), 7.98(\mathrm{~d}, 1 \mathrm{H}, J=8.3 \mathrm{~Hz})$, $8.01-8.07(\mathrm{~m}, 1 \mathrm{H}), 8.26(\mathrm{~d}, 1 \mathrm{H}, J=8.0), 8.43(\mathrm{~d}$, $1 \mathrm{H}, J=8.3 \mathrm{~Hz}) .{ }^{13} \mathrm{C} \mathrm{NMR}\left(100 \mathrm{MHz}, \mathrm{CDCl}_{3}\right) \delta$ $18.3\left(\mathrm{CH}_{3}\right), 23.6,27.6,28.4,40.1,64.6,117.9$, $118.9,120.2,121.0,125.1,125.2,125.9,126.3$, $127.5,129.9,127.7,130.1,130.5,131.5,132.3$, $136.4,136.5,140.3,163.2(\mathrm{C}=\mathrm{O}$, ring $), 163.6$ $\left(\mathrm{C}=\mathrm{O}\right.$, ring), $167.5(\mathrm{C}=\mathrm{O})$. HRMS $\left(\mathrm{EI}^{+}\right)$calcd for $\mathrm{C}_{27} \mathrm{H}_{23} \mathrm{NO}_{4} \mathrm{~S}^{+}$: 457.1348, found: 457.1362 .

\subsubsection{1,3,5-Tri-O-isobutyryl bromide benzene, $A$}

$1,3,5$-Trihydroxybenzene $(6.31 \mathrm{~g}, 50 \mathrm{mmol})$ was dissolved in anhydrous THF $(250 \mathrm{~mL})$ at $25^{\circ} \mathrm{C}$ under an atmosphere of nitrogen. Triethylamine $(23 \mathrm{~mL}, 165 \mathrm{mmol})$ was added and the mixture was cooled to $0{ }^{\circ} \mathrm{C}$ (ice bath). A solution of 2bromoisobutyryl bromide $(20.4 \mathrm{~mL}, 165 \mathrm{mmol})$ in anhydrous THF $(40 \mathrm{~mL})$ was added dropwise over a period of $1 \mathrm{~h}$. A white precipitate of triethylammonium bromide forms almost immediately. After addition of 2-bromoisobutyryl bromide, the mix- ture was stirred for $4 \mathrm{~h}$. The reaction mixture was filtered and the solvent evaporated under reduced pressure. The white/yellow powder was recrystallised from methanol and the product dried under vacuum to give the 3 -arm initiator $(25.9 \mathrm{~g}, 91 \%)$ as a white crystalline solid. Mp $48-50{ }^{\circ} \mathrm{C}$.

${ }^{1} \mathrm{H}$ NMR $\left(400 \mathrm{MHz}, \mathrm{CDCl}_{3}\right) \delta 2.04(\mathrm{~s}, 18 \mathrm{H}$, $\left.\mathrm{CH}_{3}\right), 6.96(\mathrm{~s}, 3 \mathrm{H}) .{ }^{13} \mathrm{C} \mathrm{NMR}\left(100 \mathrm{MHz}, \mathrm{CDCl}_{3}\right)$ $\delta 30.5\left(\mathrm{CH}_{3}\right), 54.8,112.5,151.3,169.4(\mathrm{C}=\mathrm{O})$. HRMS (Technique) calcd for $\mathrm{C}_{18} \mathrm{H}_{21} \mathrm{Br}_{3} \mathrm{O}_{6}^{+}$: 569.8888, found: 569.8667 .

\subsubsection{1,2,3,4,6-Penta-O-isobutyryl bromide- $\alpha-D$ - glucose, $B$}

Glucose $(50 \mathrm{~g}, 0.278 \mathrm{~mol})$ was suspended in a mixture of anhydrous pyridine $(200 \mathrm{~mL})$ and anhydrous chloroform $(350 \mathrm{~mL})$ under an atmosphere of nitrogen at $25^{\circ} \mathrm{C}$. The suspension was cooled to $0{ }^{\circ} \mathrm{C}$ and a solution of 2-bromoisobutyryl bromide $(205 \mathrm{~mL}, 1.67 \mathrm{~mol})$ in anhydrous chloroform $(100 \mathrm{~mL})$ was added dropwise over a period of $1 \mathrm{~h}$. The reaction mixture was allowed to warm to ambient temperature and stirred for 4 days. The reaction mixture was diluted with chloroform $(300 \mathrm{~mL})$ and washed successively with ice-water $(500 \mathrm{~mL})$, saturated aqueous sodium hydrogen carbonate solution $(500 \mathrm{~mL} \times 3)$, water $(500 \mathrm{~mL})$, dried $\left(\mathrm{MgSO}_{4}\right)$, filtered and evaporated to give a pale orange cake. Methanol (1 L) was added and the suspension stirred to break up the cake to give a fine suspension. The solid was filtered, washed with methanol $(2 \times 500 \mathrm{~mL})$ and dried to give product $(214.3 \mathrm{~g}, 84 \%)$ as a white powder. Mp $207-208^{\circ} \mathrm{C}$.

${ }^{1} \mathrm{H}$ NMR $\left(400 \mathrm{MHz}, \mathrm{CDCl}_{3}\right) \delta 1.82(\mathrm{~s}, 3 \mathrm{H}$, $\left.\mathrm{CH}_{3}\right), 1.85\left(\mathrm{~s}, 3 \mathrm{H}, \mathrm{CH}_{3}\right), 1.86\left(\mathrm{~s}, 3 \mathrm{H}, \mathrm{CH}_{3}\right), 1.88$ $(\times 2)\left(\mathrm{s}, 3 \mathrm{H}, \mathrm{CH}_{3}\right), 1.90\left(\mathrm{~s}, 3 \mathrm{H}, \mathrm{CH}_{3}\right), 1.91(\mathrm{~s}, 3 \mathrm{H}$, $\left.\mathrm{CH}_{3}\right), 1.94\left(\mathrm{~s}, 3 \mathrm{H}, \mathrm{CH}_{3}\right), 1.85\left(\mathrm{~s}, 3 \mathrm{H}, \mathrm{CH}_{3}\right), 2.01$ $\left(\mathrm{s}, 3 \mathrm{H}, \mathrm{CH}_{3}\right), 4.31-4.42(\mathrm{~m}, 3 \mathrm{H}), 5.23(\mathrm{dd}, 1 \mathrm{H}$, $J=3.8,10.2 \mathrm{~Hz}), 5.27-5.36(\mathrm{~m}, 1 \mathrm{H}), 5.67(\mathrm{t}, 1 \mathrm{H}$, $J=9.8 \mathrm{~Hz}), 6.39(\mathrm{~d}, 1 \mathrm{H}, J=3.8 \mathrm{~Hz}) .{ }^{13} \mathrm{C} \mathrm{NMR}$ $\left(100 \mathrm{MHz}, \mathrm{CDCl}_{3}\right) \delta 30.1\left(\mathrm{CH}_{3}\right), 30.2\left(\mathrm{CH}_{3}\right)$, $30.3\left(\mathrm{CH}_{3}\right), 30.4(\mathrm{x} 3)\left(\mathrm{CH}_{3}\right), 30.5\left(\mathrm{CH}_{3}\right), 30.6$ $(\times 2)\left(\mathrm{CH}_{3}\right), \quad 30.7\left(\mathrm{CH}_{3}\right), 54.8,54.9,55.0,55.3$ $(\times 2), \quad 62.5, \quad 68.0, \quad 70.1, \quad 70.4, \quad 70.5, \quad 89.4,169.2$ $(\mathrm{C}=\mathrm{O}), \quad 169.7 \quad(\mathrm{C}=\mathrm{O}), \quad 170.2 \quad(\mathrm{C}=\mathrm{O}), \quad 170.3$ $(\mathrm{C}=\mathrm{O}), 171.1(\mathrm{C}=\mathrm{O})$. HRMS (Technique) calcd for $\mathrm{C}_{26} \mathrm{H}_{37} \mathrm{Br}_{5} \mathrm{O}_{11}^{+}$: 919.8253, found: 919.8482 . 


\subsection{Synthesis of 8-arm initiator, $C$}

Lactose ( $30 \mathrm{~g}, 87.63 \mathrm{mmol})$ was suspended in a mixture of anhydrous pyridine $(200 \mathrm{~mL})$ and anhydrous chloroform $(200 \mathrm{~mL})$ under an atmosphere of nitrogen at $25^{\circ} \mathrm{C}$. The suspension was cooled to $0{ }^{\circ} \mathrm{C}$ and a solution of 2-bromoisobutyryl bromide $(104 \mathrm{~mL}, 0.841 \mathrm{~mol})$ in anhydrous chloroform $(100 \mathrm{~mL})$ was added dropwise over a period of $1 \mathrm{~h}$. The reaction mixture was allowed to warm to $25^{\circ} \mathrm{C}$ and stirred for 3 days. The reaction mixture was diluted with chloroform $(300 \mathrm{~mL})$ and washed successively with ice-water $(500 \mathrm{~mL})$, saturated aqueous sodium hydrogen carbonate $(3 \times 500 \mathrm{~mL})$, water $(500 \mathrm{~mL})$, dried $\left(\mathrm{MgSO}_{4}\right)$, filtered and evaporated to give an orange transparent solid/syrup. Ethanol $(500 \mathrm{~mL})$ was added to the solid and heated to boiling to break up the solid. The mixture was allowed to cool and the solid filtered, washed with light petroleum and dried to give product, C $(128.5 \mathrm{~g}, 96 \%)$ as a white powder. Mp 219-220 ${ }^{\circ} \mathrm{C}$.

${ }^{1} \mathrm{H}$ NMR (400 MHz, $\left.\mathrm{CDCl}_{3}\right) \delta 1.77\left(\mathrm{CH}_{3}\right), 1.86$ $\left(\mathrm{CH}_{3}\right), 1.87\left(\mathrm{CH}_{3}\right), 1.88\left(\mathrm{CH}_{3}\right), 1.89\left(\mathrm{CH}_{3}\right), 1.90$ $\left(\mathrm{CH}_{3}\right), 1.92\left(\mathrm{CH}_{3}\right), 1.93\left(\mathrm{CH}_{3}\right), 1.94\left(\mathrm{CH}_{3}\right), 1.94$ $\left(\mathrm{CH}_{3}\right), 1.95\left(\mathrm{CH}_{3}\right), 1.96\left(\mathrm{CH}_{3}\right), 2.00\left(\mathrm{CH}_{3}\right), 2.00$ $\left(\mathrm{CH}_{3}\right), 2.00\left(\mathrm{CH}_{3}\right), 2.02\left(\mathrm{CH}_{3}\right), 4.16-4.26(\mathrm{~m}$, $3 \mathrm{H}), 4.29-4.39(\mathrm{~m}, 2 \mathrm{H}), 4.48(\mathrm{dd}, 1 \mathrm{H}, J=2.0$, $12.8 \mathrm{~Hz}), 4.69(\mathrm{dd}, 1 \mathrm{H}, J=2.5,12.8 \mathrm{~Hz}), 4.73(\mathrm{~d}$, $1 \mathrm{H}, J=8.3 \mathrm{~Hz}), 5.00(\mathrm{dd}, 1 \mathrm{H}, J=3.3,10.5 \mathrm{~Hz})$, $5.07(\mathrm{dd}, 1 \mathrm{H}, J=3.8,10.3 \mathrm{~Hz}), 5.25(\mathrm{dd}, 1 \mathrm{H}$, $J=8.0,10.5 \mathrm{~Hz}), 5.49(\mathrm{~d}, 1 \mathrm{H}, J=3.3 \mathrm{~Hz}), 5.63$ $(\mathrm{t}, 1 \mathrm{H}, J=9.8 \mathrm{~Hz}), 6.32(\mathrm{~d}, 1 \mathrm{H}, J=3.5 \mathrm{~Hz}) \cdot{ }^{13} \mathrm{C}$ NMR $\left(100 \mathrm{MHz}, \mathrm{CDCl}_{3}\right) \delta 30.0,30.1,30.2,30.3$ $(\times 2), 30.4,30.5(\times 4), 30.6(\times 3), 30.7,30.8,31.1$ $\left(\mathrm{CH}_{3} \times 16\right), 54.4,54.9,55.1,55.2,55.3,55.5,55.6$, $56.4,62.3,62.8,68.3,69.6,70.2,70.8,70.8,71.0$, $72.9,73.0,89.1,99.6,169.2,169.3,170.3,170.4$ $(\mathrm{C}=\mathrm{O}), \quad 170.5 \quad(\mathrm{C}=\mathrm{O}), \quad 170.6 \quad(\mathrm{C}=\mathrm{O}), \quad 170.9$ $(\mathrm{C}=\mathrm{O}), 171.0(\mathrm{C}=\mathrm{O})$. HRMS (Technique) calcd for $\mathrm{C}_{44} \mathrm{H}_{62} \mathrm{Br}_{8} \mathrm{O}_{19}^{+}$: 1525.7352, found: 1525.6843 .

\subsection{Preparation of 3-arm fluorescent DMAEMA star polymer}

$\mathrm{Cu}^{\mathrm{I}} \mathrm{Br} \quad(0.426 \mathrm{~g}, \quad 3 \mathrm{mmol}), \quad$ D, $\quad(0.678 \mathrm{~g}$, $1.5 \mathrm{mmol})$ and initiator, A, $(0.564 \mathrm{~g}, 1 \mathrm{mmol})$ were weighed out into a Schlenk tube and sealed with a subaseal then pump-filled with nitrogen three times. DMAEMA $(50 \mathrm{~mL}, 0.3 \mathrm{~mol})$, toluene $(140 \mathrm{~mL})$ and $n$-propyl-2-pyridinylmethyleneamine $(0.96 \mathrm{~mL}, 6 \mathrm{mmol})$ were added. The mixture was frozen in liquid nitrogen and degassed via three freeze-pump-thaw cycles. The reaction mixture, under an atmosphere of nitrogen, was placed in a oil bath at $85^{\circ} \mathrm{C}$ and stirred for $3.5 \mathrm{~h}$. The polymerisation was followed by ${ }^{1} \mathrm{H}$ NMR. After $3.5 \mathrm{~h}$, the reaction mixture was removed from the oil bath, diluted with toluene $(\sim 100 \mathrm{~mL})$ and filtered through a column of basic alumina to remove the copper catalyst; the filtrate was evaporated under reduced pressure. The polymer was dissolved in chloroform $(\sim 120 \mathrm{~mL})$ and added dropwise to petroleum ether with vigorous stirring to precipitate the polymer. The solvent was removed by suction filtration to give star polymer $(24 \mathrm{~g})$ as a orange crystalline solid; $M_{\mathrm{n}}=12,300 \mathrm{~g} \mathrm{~mol}^{-1}, \quad$ PDI $=$ 1.09 .

\subsection{Preparation of 5-arm fluorescent DMAEMA star polymer}

$\mathrm{Cu}^{\mathrm{I}} \mathrm{Br}(0.426 \mathrm{~g}, 3 \mathrm{mmol})$, monomer $\mathbf{D}(0.678 \mathrm{~g}$, $1.5 \mathrm{mmol})$ and initiator $\mathbf{B}(0.552 \mathrm{~g}, 0.6 \mathrm{mmol})$ were weighed out into a Schlenk tube and sealed with a subaseal then pump-filled with nitrogen three times. DMAEMA $(50 \mathrm{~mL}, 0.3 \mathrm{~mol})$, toluene $(140 \mathrm{~mL})$ and $n$-propyl-2-pyridinylmethyleneamine $(0.96 \mathrm{~mL}, 6 \mathrm{mmol})$ were added. Procedure above was followed to give 5-arm star polymer $(20 \mathrm{~g})$ as a orange crystalline solid; $M_{\mathrm{n}}=$ $18,700 \mathrm{~g} \mathrm{~mol}^{-1}$, PDI $=1.10$.

\subsection{Preparation of 8-arm fluorescent DMAEMA star polymer}

$\mathrm{Cu}^{\mathrm{I}} \mathrm{Br}(0.426 \mathrm{~g}, 3 \mathrm{mmol})$, monomer $\mathbf{D}(0.678 \mathrm{~g}$, $1.5 \mathrm{mmol})$ and initiator $\mathbf{C}(0.566 \mathrm{~g}, 0.38 \mathrm{mmol})$ were weighed out into a Schlenk tube and sealed with a subaseal then pump-filled with nitrogen three times. DMAEMA ( $50 \mathrm{~mL}, 0.3 \mathrm{~mol}$ ), toluene $(140 \mathrm{~mL})$ and $n$-propyl-2-pyridinylmethyleneamine $(0.96 \mathrm{~mL}, 6 \mathrm{mmol})$ were added. Procedure above was followed to give star polymer $(19 \mathrm{~g})$ as 
a orange crystalline solid; $M_{\mathrm{n}}=39,200 \mathrm{~g} \mathrm{~mol}^{-1}$, PDI $=1.11$.

\subsection{General procedure for quaternisation of pDMAEMA star polymers with methyl iodide}

Polymer $(1 \mathrm{~g})$ was dissolved in anhydrous THF $(75 \mathrm{~mL})$ at $25^{\circ} \mathrm{C}$ under an atmosphere of nitrogen. Methyl iodide $(0.39 \mathrm{~mL}, 6.3 \mathrm{mmol})$ was added and the mixture stirred at $25^{\circ} \mathrm{C}$ for $7 \mathrm{~h}$. Precipitation of the polymer starts to occur after approximately $20-30 \mathrm{~min}$. The reaction mixture was diluted with hexane and the quaternised polymer was filtered.

\subsection{General procedure for protonation of pDMAEMA star polymers with $\mathrm{HCl}$}

Polymer $(1 \mathrm{~g})$ was dissolved in $20 \mathrm{~mL}$ of $1 \mathrm{M}$ $\mathrm{HCl}(\mathrm{aq})$ with stirring. The orange colored solution was frozen in liquid nitrogen and freeze-dried to give quaternised pDMAEMA star polymers as brown/orange crystalline solids.

\subsection{Preparation of 5-arm MMA star polymer}

$\mathrm{Cu}^{\mathrm{I}} \mathrm{Br}(0.4 \mathrm{~g}, 2.8 \mathrm{mmol})$ and initiator $\mathbf{B}(0.51 \mathrm{~g}$, $0.56 \mathrm{mmol}$ ) were weighed out into a Schlenk tube and sealed with a subaseal then pump-filled with nitrogen three times. MMA ( $30 \mathrm{~mL}, 0.28 \mathrm{~mol})$, toluene $(140 \mathrm{~mL})$ and $n$-propyl-2-pyridinylmethyleneamine $(0.94 \mathrm{~mL}, 5.8 \mathrm{mmol})$ were added. The mixture was frozen in liquid nitrogen and degassed via three freeze-pump-thaw cycles. The reaction mixture, under an atmosphere of nitrogen, was placed in a oil bath at $75^{\circ} \mathrm{C}$ and stirred for $3.5 \mathrm{~h}$. The polymerisation was followed by ${ }^{1} \mathrm{HNMR}$. After $6 \mathrm{~h}$, the reaction mixture was removed from the oil bath, diluted with toluene $(\sim 100 \mathrm{~mL})$ and filtered through a column of basic alumina to remove the copper catalyst, the filtrate was evaporated under reduced pressure. The polymer was dissolved in acetone $(\sim 75 \mathrm{~mL})$ and added dropwise to petroleum ether with vigorous stirring to precipitate the polymer. The solvent was removed by suction filtration to give star polymer $(8 \mathrm{~g})$ as a white crystalline solid; $M_{\mathrm{n}}=$ $15,000 \mathrm{~g} \mathrm{~mol}^{-1}$, PDI $=1.09$.

\subsection{Preparation of 5-arm $M M A-D M A E M A$} star block co-polymer

$\mathrm{Cu}^{\mathrm{I}} \mathrm{Br}(0.11 \mathrm{~g}, 0.8 \mathrm{mmol}$ and 5-arm methyl methacrylate star polymer $(2.5 \mathrm{~g})$ were weighed out into a Schlenk tube and sealed with a subaseal then pumpfilled with nitrogen three times. DMAEMA $(13.5 \mathrm{~mL}, 0.08 \mathrm{~mol})$, toluene $(47 \mathrm{~mL})$ and $n$-propyl-2-pyridinylmethyleneamine $\quad(0.27 \mathrm{~mL}, \quad 1.68$ $\mathrm{mmol}$ ) were added. The mixture was frozen in liquid nitrogen and degassed via three freeze-pump-thaw cycles. The reaction mixture, under an atmosphere of nitrogen, was placed in a oil bath at $85^{\circ} \mathrm{C}$ and stirred for $3.5 \mathrm{~h}$. The polymerisation was followed by ${ }^{1} \mathrm{H}$ NMR. After $3.5 \mathrm{~h}$, the reaction mixture was removed from the oil bath, diluted with toluene $(\sim 100 \mathrm{~mL})$ and filtered through a column of basic alumina to remove the copper catalyst, the filtrate was evaporated under reduced pressure. The polymer was dissolved in acetone $(\sim 100 \mathrm{~mL})$ and added dropwise to petroleum ether with vigorous stirring to precipitate the polymer. The solvent was removed by suction filtration to give star polymer $(11 \mathrm{~g})$ as a orange crystalline solid; $M_{\mathrm{n}}=64,300 \mathrm{~g} \mathrm{~mol}^{-1}$, $\mathrm{PDI}=1.29$.

\subsection{Adhesion to biosurfaces}

The hostosol tagged 3-arm-poly(DMAEMA) polymer was used for this study. A rat was euthanised by cervical dislocation and a range of epithelial tissue samples of between 100 and $200 \mathrm{mg}$ weight were rapidly dissected within $10 \mathrm{~min}$ of death. These were immediately immersed in $5 \mathrm{ml}$ of pre-gassed Krebs solution containing $1 \mathrm{mg} \mathrm{ml}^{-1}$ of the test polymer. This was maintained at $37^{\circ} \mathrm{C}$ and $\mathrm{pH} 7.6$ for $10 \mathrm{~min}$. The medium was then removed, and the tissue washed twice for $30 \mathrm{~s}$ in an equal volume Krebs solution before coating it in OCT cryoembedding medium (Sakura Finetek, Europe). After the samples were embedded, they were frozen in liquid nitrogen, mounted on a metal chuck, and cryosectioned at $7 \mu \mathrm{m}$, using a Bright OTF/AS cryomicrotome. Frozen tissue sections were then dried onto on Biobond (Electron Microscopy Sciences) coated glass microscope slides, and allowed to dry at ambient temperature for $10 \mathrm{~min}$. Consecutive sections were then either 
left unstained, or counterstained in Harris's haematoxylin. They were then mounted in fluorescent mounting medium (Dako, product code S3023), and coverslipped. Sections were viewed with a $\mathrm{Ni}$ kon Eclipse E400 microscope, equipped for transmitted and epifluorescence microscopy, and digital photography. Initially, counterstained sections were viewed by transmitted light to orientate the tissue, and to identify where the epithelium and lumen were located. This enabled the subsequent identification of the correct region of unstained sections for viewing under epifluorescence using the filter set normally used for fluorescein isothiocyanate (FITC).

\subsection{Results}

Multi-functional initiators, A-C, were prepared by the condensation of 2-bromoisobutyryl bromide with 1,3,5-trihydroxybenzene, glucose and lactose to produce 3-, 5- and 8-arm initiators, respectively. Initiators were purified before use and were found to be highly soluble in all common solvents used for copper mediated LRP.

\subsection{Poly(DMAEMA) star polymer synthesis}

Multi-functional initiators were used as initiators for the copper mediated LRP of DMAEMA to produce 3-, 5- and 8-arm star polymers. Initially, the polymerisation of DMAEMA was carried out with an $[\mathrm{M}] /[\mathrm{I}]$ ratio of $60: 1$ at $85^{\circ} \mathrm{C}$ in toluene at $50 \mathrm{wt} \%$ where $[\mathrm{M}]$ and $[\mathrm{I}]$ are the initial concentrations of monomer and initiation sites on the multi-functional initiators, respectively. Monomer D $(0.5 \mathrm{~mol} \%)$ was added to the reac- tion medium to yield fluorescently tagged polymers. Relatively narrow polydispersity star polymers were achieved up to $45 \%$ conversion after $2 \mathrm{~h}$. At higher conversions, e.g., $85 \%$ after $5 \mathrm{~h}$, the SEC traces showed a bimodal peak, this was evident as a shoulder on the main peak in the higher molecular weight region. This is ascribed to termination via irreversible coupling of two star polymers. Three measures were taken to rectify this problem. Firstly, the reaction was conducted at a lower temperature; secondly the ratio of monomer to initiator was increased to 100:1 and finally the level of solvent was increased to $73 \%$ vol $\%$, Table 1 . The linear first order kinetic plots, Fig. 2, indicate that the concentration of propagating species is constant throughout the reaction. The molecular weights increase with conversion/reaction time, polydispersity also remained narrow throughout, Table 1. An overlay of the GPC data obtained is shown in Fig. 3.

Fig. 4 shows the evolution of $M_{\mathrm{n}}$ and PDI of the polymer as a function of monomer conversion. The $M_{\mathrm{n}}$ increased with increasing conversion and the PDI remained narrow throughout the reaction, as would be expected for a living polymerisation. The $M_{\mathrm{n}}$ values obtained by SEC calibrated with linear PMMA standards differ substantially from than the theoretical values calculated from the consumed monomer and initial concentration of initiator. Molecular weight of the arms was measured by detaching the arms from the core via a hydrolysis reaction and remethylation to render the linear polymer THF soluble. The molecular weight of the polymer lies close to the predicted molecular weight, Fig. 5.

Table 1

DMAEMA and monomer D polymerisation data; all reactions conducted at $85{ }^{\circ} \mathrm{C}, 73 \%$ toluene, [Monomer]:[Initiating site] $=100$

\begin{tabular}{|c|c|c|c|c|c|}
\hline Initiator & Time $(\min )$ & Conversion (\%) & $M_{\mathrm{n}, \mathrm{Theo}} / \mathrm{g} \mathrm{mol}^{-1}$ & $M_{\mathrm{n}, \mathrm{SEC}} / \mathrm{g} \mathrm{mol}^{-1}$ & $M_{\mathrm{w}} / M_{\mathrm{n}}(\mathrm{PDI})$ \\
\hline A & 30 & 12.4 & 6100 & 3300 & 1.08 \\
\hline A & 90 & 27.0 & 13,200 & 6500 & 1.08 \\
\hline A & 210 & 50.9 & 24,500 & 12,200 & 1.09 \\
\hline B & 30 & 7.8 & 7000 & 6100 & 1.10 \\
\hline B & 90 & 24.7 & 20,300 & 10,700 & 1.10 \\
\hline B & 210 & 51.3 & 40,800 & 18,900 & 1.10 \\
\hline $\mathrm{C}$ & 30 & 6.5 & 8700 & 9900 & 1.10 \\
\hline $\mathrm{C}$ & 90 & 21.4 & 27,500 & 21,800 & 1.07 \\
\hline $\mathrm{C}$ & 210 & 48.3 & 61,300 & 38,400 & 1.11 \\
\hline
\end{tabular}




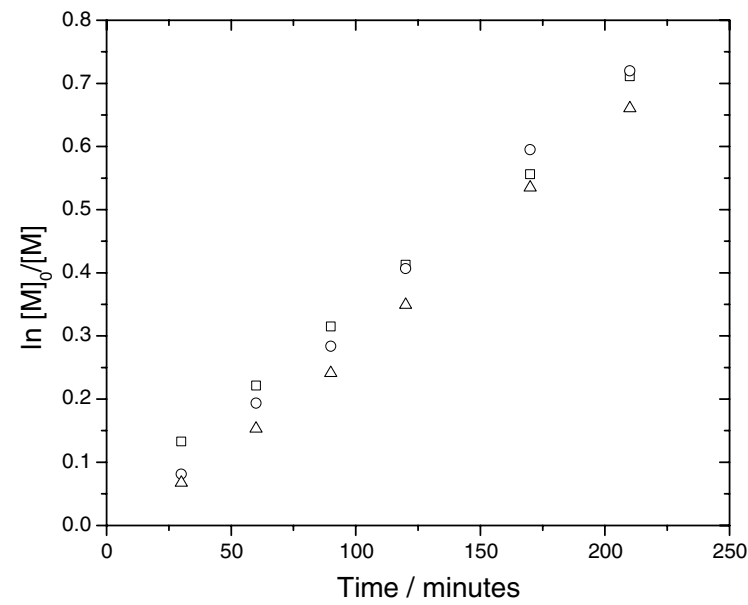

Fig. 2. First order kinetic plots for the polymerisation of DMAEMA and hostasol monomer with multi-functional initiators. All reactions conducted at $85^{\circ} \mathrm{C}, 73 \%$ toluene, [Monomer]:[Initiating site] $=100 \quad \square=3$-arm $\triangle=5$-arm $\mathrm{O}=8$-arm

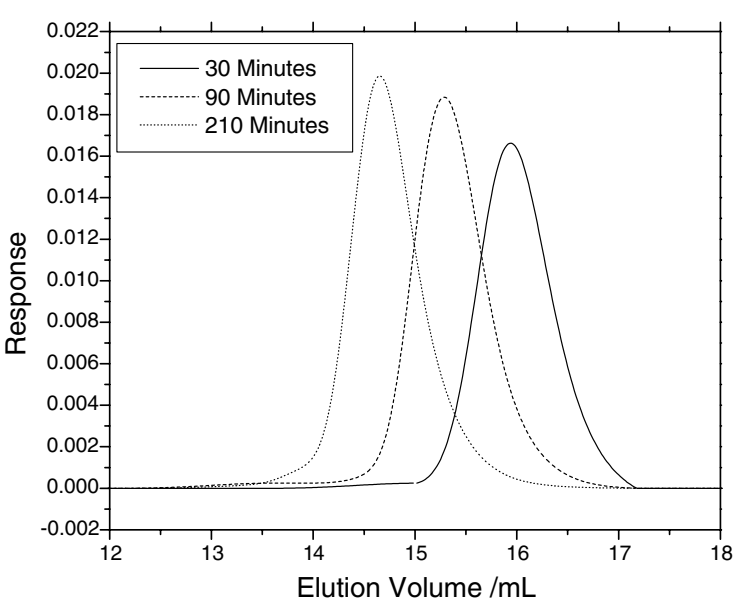

Fig. 3. SEC overlay plots for the preparation of a 3-arm DMAEMA star polymer; reaction conducted at $85^{\circ} \mathrm{C}, 73 \%$ toluene, [Monomer]:[Initiating site] $=100$.

\subsection{MMA and DMAEMA star block co-polymer synthesis}

A series of well defined multi-arm PolyDMAEMA polymers containing a tag that fluoresces in the visible region were prepared. Star block co-polymers of MMA and DMAEMA were produced containing the fluorescent tag in either the

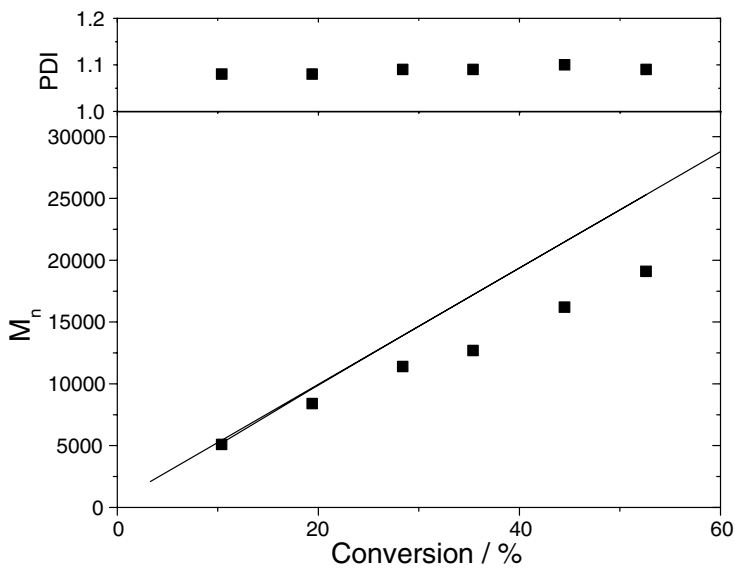

Fig. 4. Evolution of $M_{\mathrm{n}}$ and polydispersity as a function of monomer conversion for the preparation of a 3-arm DMAEMA star polymer. Reaction conducted at $85^{\circ} \mathrm{C}, 73 \%$ toluene, [Monomer]:[Initiating site $]=100$.

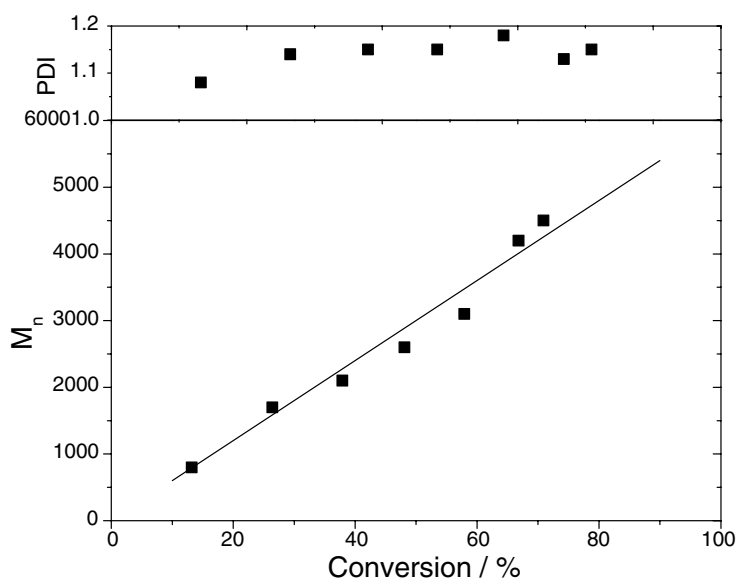

Fig. 5. Evolution of $M_{\mathrm{n}}$ and PDI as a function of monomer conversion for the preparation of a 3-arm DMAEMA star polymer. Molecular weight determined after the hydrolysis of the polymer to detach the individual arms. Solid line shows predicted molecular weight from monomer conversion and initial initiator concentration.

MMA block or the DMAEMA block. Firstly 5arm MMA star polymers was prepared at $75^{\circ} \mathrm{C}$ and stopped at low conversion, to ensure termination events were kept to a minimum, Fig. 6. Both the PMMA star and fluorescently labeled PMMA star polymers were isolated, purified and 


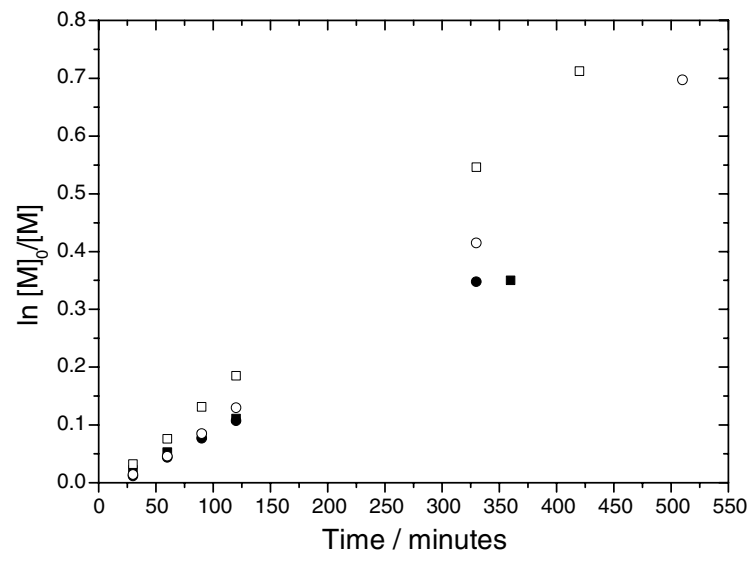

Fig. 6. First order kinetic plots for the polymerisation of MMA with initiator $\mathbf{A}$ and for the subsequent polymerisation of DMAEMA to form star block co-polymers. $=\mathrm{P}($ MMA) star $\boldsymbol{0}=\mathrm{P}($ MMA-co-D) star $\square=\mathrm{P}($ MMA)-P(DMAEMA-co-D) star $\bigcirc=\mathrm{P}($ MMA-co-D)-P(DMAEMA) star.

characterized prior to being utilized as macroinitiators for subsequent polymerisation of DMAEMA. Polymerisation proceeded successfully in both cases to yield two fluorescent 5-arm star polymers, Fig. 6.

Fig. 7 shows SEC traces for the P(MMA) macroinitiator and the labeled $\mathrm{P}(\mathrm{MMA}) \mathrm{P}(\mathrm{DMA}-$ EMA-co-D) star polymer, showing the expected molecular weight increase with good evidence for

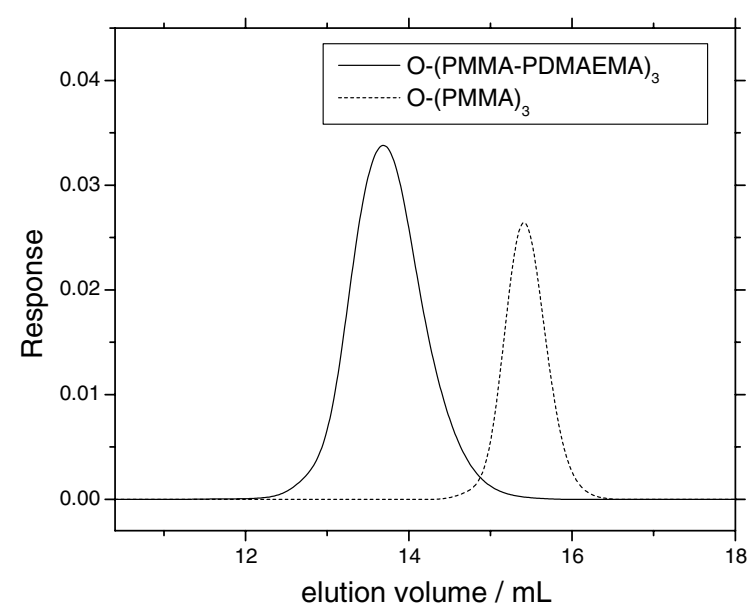

Fig. 7. SEC plots for a 3-arm PMMA star macroinitiator and 3-arm PMMA-PDMAEMA star block co-polymer. efficient reinitiation. Molecular weight data for the star polymers is given in Table 2. Differences between theoretical and measured are ascribed to the use of linear standards for SEC calibration.

\subsection{Fluorescence characteristics of labeled polymers}

The fluorescence of the labeled multi-arm polymers in various forms: (i) native polymer, (ii) the hydrochloride salt and (iii) iodomethane quaternised derivative were studied. All polymers showed fluorescence over a range of $\mathrm{pH}$. The most intense fluorescence was observed with the polymeric hydrochloride salts. Consequently these derivatives were used for detailed studies. The peak excitation frequency of the fluorescent tag was determined by UV spectrometry. Fluorescence samples were prepared at a variety of $\mathrm{pH}$ 's from 1.2 to 12 . Solutions were prepared at a concentration of $0.5 \mathrm{mg} \mathrm{mL}^{-1}$ and the emission spectra was recorded between $300 \mathrm{~nm}$ and $700 \mathrm{~nm}$ at a scan rate of $200 \mathrm{~nm}$ per min with $\lambda_{\mathrm{ex}}=462 \mathrm{~nm}$. Fluorescence spectra recorded for the 3-, 5- and 8 -arm star polymers, respectively, Fig. 8, Table 3.

All of the multi-arm polymers exhibit fluorescence across a broad $\mathrm{pH}$ range with maximum emission at $\mathrm{pH} 4$; the intensity reduced significantly as the $\mathrm{pH}$ is increased. On the addition of $\mathrm{HCl}$ to the polymer the hydrochloride salt is formed with the tertiary amine. As the $\mathrm{pH}$ is increased the salt is neutralized which reduces the hydrophilicity of the polymer. This allows aggregation of the fluorophore which in turn lowers the intensity of emission. Fluorescence spectra of the 5- and 8-arm star block co-polymers were recorded using the same conditions, Fig. 9, Table 4.

The fluorescence data exhibit some interesting trends, it is noted that at $\mathrm{pH} 12$ the polymers were no longer fully water soluble. The star block copolymers are not water soluble until the DMAEMA component is converted into the $\mathrm{HCl}$ salt. The fluorescence spectra recorded of the P(MMA)-P(DMAEMA-co-Hostasol) star polymer exhibit the same trends as observed with the homopolymer stars. The fluorescence spectra recorded of the P(MMA-co-Hostasol)-P(DMAEMA) star polymer show no change in 
Table 2

Conversion and molecular weight data for the preparation of MMA and DMAEMA star polymers

\begin{tabular}{llll}
\hline Polymer & $M_{\mathrm{n}, \mathrm{Theo}} / \mathrm{g} \mathrm{mol}^{-1}$ & $M_{\mathrm{n}, \mathrm{SEC}} / \mathrm{g} \mathrm{mol}^{-1}$ & $M_{\mathrm{w}} / M_{\mathrm{n}} \mathrm{PDI}$ \\
\hline P(MMA) & 17,200 & 15,000 & 1.09 \\
P(MMA-co-Hostasol) & 18,400 & 16,800 & 1.08 \\
P(MMA)-P(DMAEMA-co-Hostasol) & 76,000 & 69,900 & 1.26 \\
P(MMA-co-Hostasol)-PDMAEMA & 72,400 & 64,300 & 1.29
\end{tabular}

fluorescence behavior with change in $\mathrm{pH}$. The small differences observed are within acceptable limits of experimental error. This observation is as expected as in the case of the P(MMA-coHostasol)-P(DMAEMA) star polymer the fluorescent probe is in a region of the polymer unaffected

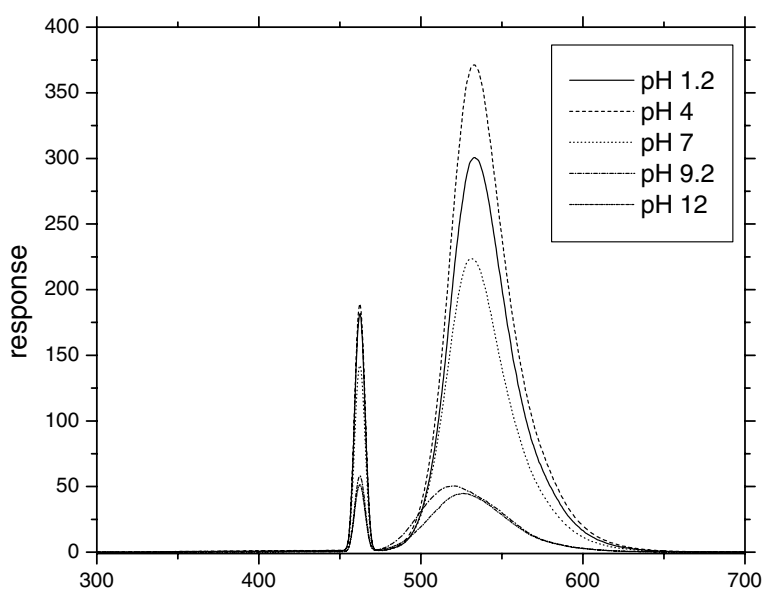

$\mathbf{a}$ by the changes in $\mathrm{pH}$. The polymers aggregate and/or form micelles in solution and in the case of the P(MMA-co-Hostasol)-P(DMAEMA) star polymers the fluorescent probe is contained within the hydrophobic region of the aggregates/micelles and hence unaffected by the $\mathrm{pH}$ changes.

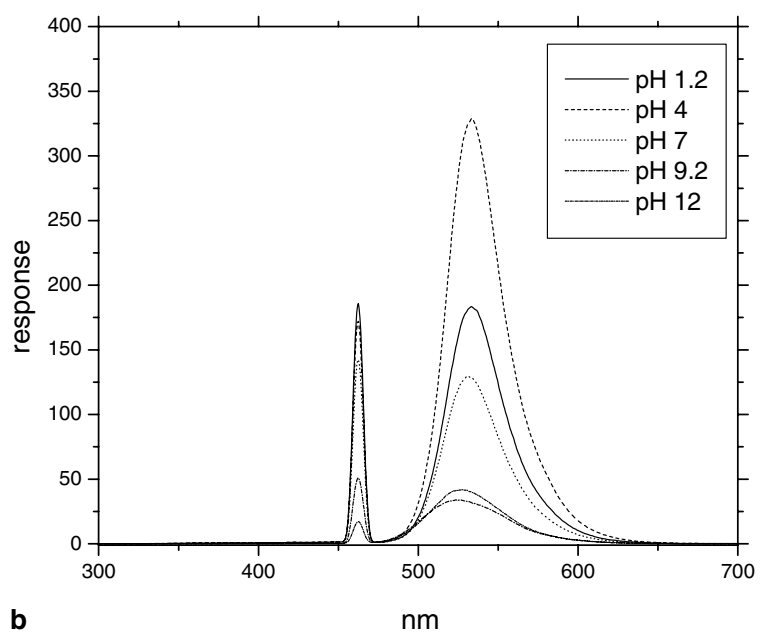

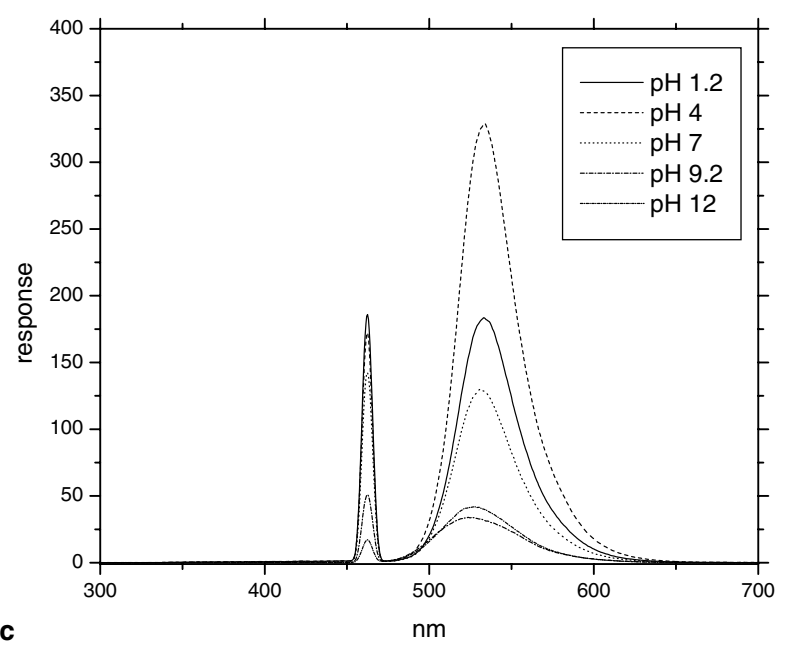

Fig. 8. Emission spectra of (a) 3-arm (b) 5-arm and (c) 8-arm PDMAEMA star polymers over a range of pH. 
Table 3

Fluorescence data for labeled star polymers

\begin{tabular}{llll}
\hline Solution $\mathrm{pH}$ & Emission intensity $(\lambda / \mathrm{nm}) ; 3$-arm & Emission intensity $(\lambda) ; 5$-arm & Emission intensity $(\lambda) ; 8$-arm \\
\hline 1.2 & $300.7(533)$ & $221.7(533.5)$ & $183.4(533)$ \\
4 & $371.2(533)$ & $393.9(533)$ & $329.1(533.5)$ \\
7 & $223.7(530.5)$ & $165.1(531.5)$ & $129.8(531)$ \\
9.2 & $50.47(520.5)$ & $43.9(520.5)$ & $33.9(523.5)$ \\
12 & $44.79(526)$ & $38.3(522.5)$ & $41.8(527.5)$
\end{tabular}
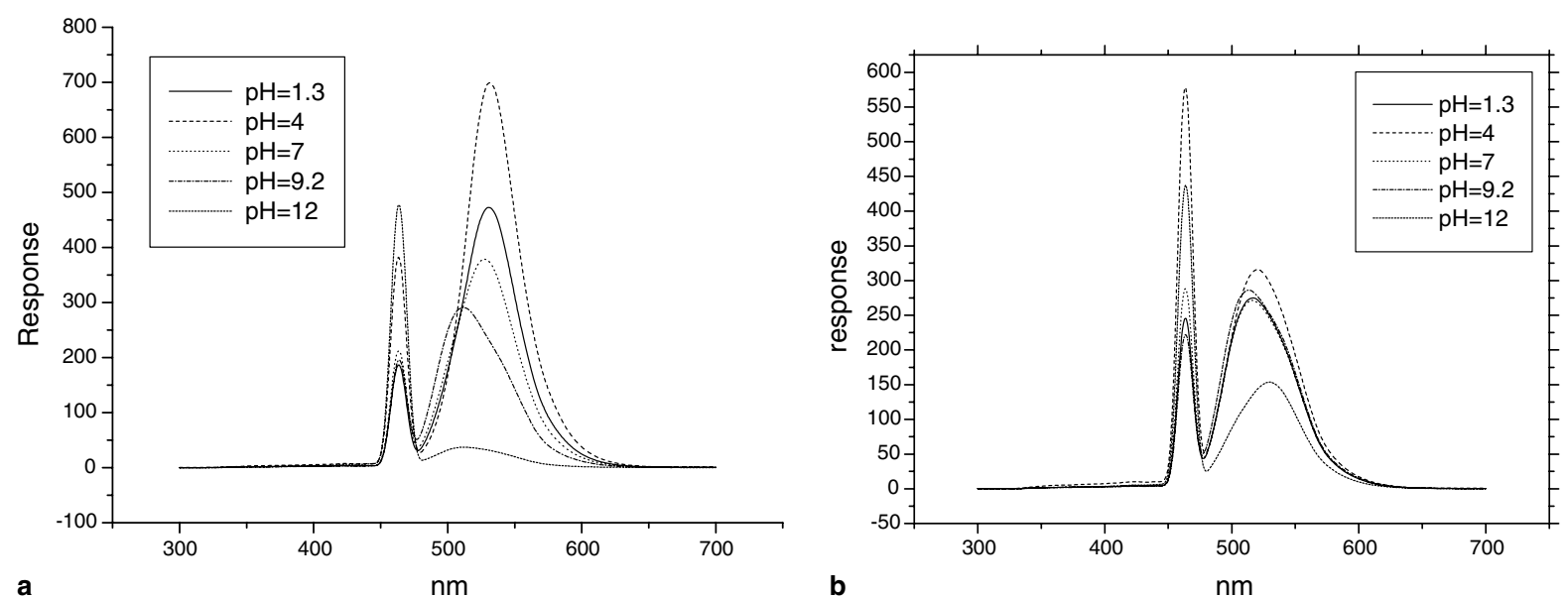

Fig. 9. Emission spectra of P(MMA)-P(DMAEMA-co-Hostasol) star polymer recorded at a variety of pH's.

\subsection{Adhesion to bio tissue}

A study was conducted to compare the adhesion of the (3-arm-poly-DMAEMA) to mucosal surfaces throughout the alimentary canal, Fig. 10. These images indicate that polymer adhesion is low in epithelial tissues not covered

Table 4

Fluorescence data for star block polymers.

\begin{tabular}{lll}
\hline $\begin{array}{l}\text { Solution } \\
\mathrm{pH}\end{array}$ & $\begin{array}{l}\text { Emission Intensity } \\
(\lambda / \mathrm{nm}) \mathrm{P}(\mathrm{MMA})\end{array}$ & $\begin{array}{l}\text { Emission Intensity } \\
(\lambda / \mathrm{nm}) \text { P(MMA-co-Hostasol) } \\
\text {-P(DMAEMA- } \\
\text { co-Hostasol) }\end{array}$ \\
\hline 1.2 & $472.8(530.5)$ & $274.8(517)$ \\
4 & $699.2(531.5)$ & $315.9(520.5)$ \\
7 & $378.7(527.5)$ & $271.4(516)$ \\
9.2 & $290.9(511.5)$ & $286.2(513.5)$ \\
12 & $37.1(512.0)$ & $153.6(530)$
\end{tabular}

by a viscoelastic mucus gel (oral cavity-A and oesophagus-B). It is noteworthy that only the tips of the lingual papilla have an affinity for the polymer (arrows in 'A'). In contrast, the epithelia of the gastrointestinal tract $(\mathrm{C}-\mathrm{H})$ display a mucus gel that binds large amounts of the polymer. In the stomach, caecum and colon, the polymer is retained in the surface mucus layer, whereas in the small intestine it penetrates into the intestinal crypts (arrows in D, and E). The trachea $(\mathrm{H})$ was included as a control. It is not part of the gastrointestinal tract, but is nevertheless covered in a viscoelastic mucus gel. It displays a punctate pattern of polymer binding. The use of identical conditions of epi-illumination for all sections facilitated comparison between different epithelial tissues. The resulting micrographs were compiled into a photo-montage to facilitate comparison, Fig. 10. 

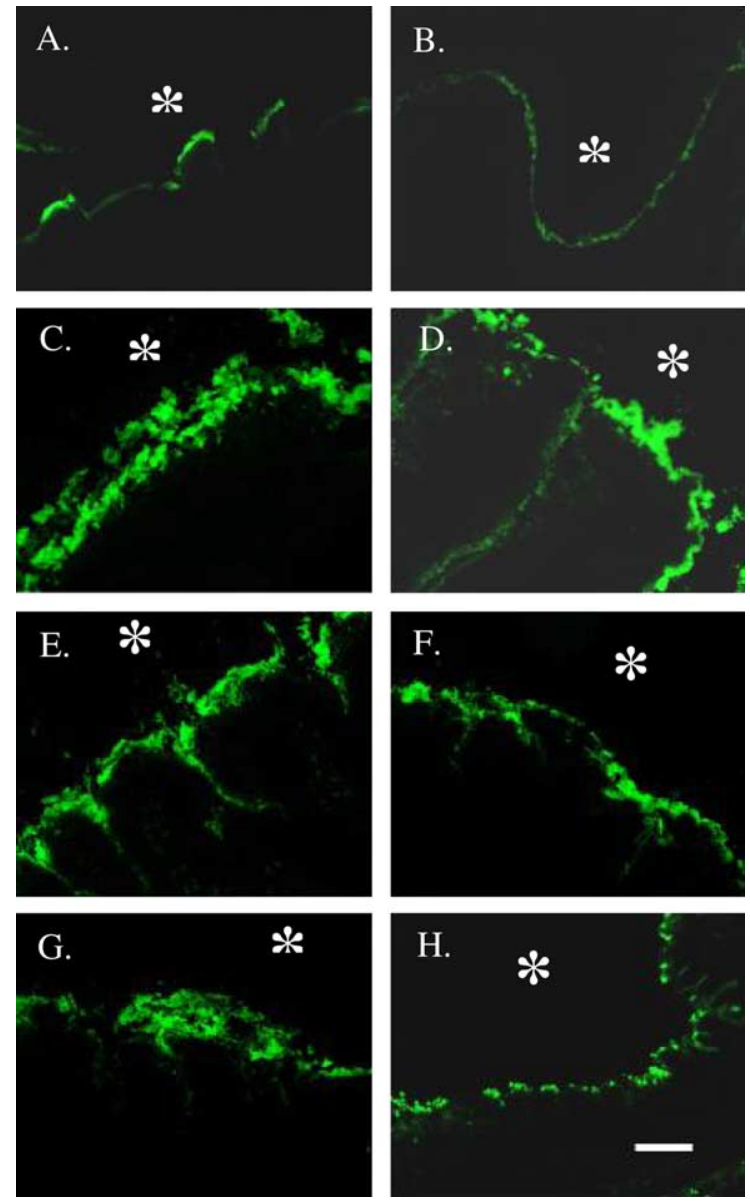

Fig. 10. Fluorescence photomicrographs of rat gastrointestinal epithelial tissues exposed to hostosol-tagged 3-arm pDMAEMA: (A) tongue, (B) oesophagus, (C) gastric fundus (D) duodenum $(\mathrm{E})$ jejunum, $(\mathrm{F})$ caecum $(\mathrm{G})$ colon $(\mathrm{H})$ Trachea (control); $*=$ lumen, bar $=100 \mu \mathrm{M}$.

\section{Conclusion}

Multi-arm, fluorescently tagged star polymers have been successfully prepared using copper(I) mediated LRP. The system has also been demonstrated to be useful for the preparation of tagged star block co-polymers. The fluorescence properties of these polymers were also studied and the effects of changes in system $\mathrm{pH}$ were noted. A 3-arm star polymer has been demonstrated to how good bioadhesion which is reduced adhesion in epithelial tissues not covered by a viscoelastic mucus gel indicating an increased tendency for mucoadhesion.

\section{Acknowledgements}

We thank Clariant for the kind donation of the hostasol precursor and Genzyme for part funding this work. D.M. Haddleton would also like to thank Professor John Ebdon for all of his encouragement and support throughout his academic career.

\section{References}

[1] J.H. Xia, X. Zhang, K. Matyjaszewski, Macromolecules 32 (1999) 4482.

[2] K. Matyjaszewski, P.J. Miller, J. Pyun, G. Kickelbick, S. Diamanti, Macromolecules 32 (1999) 6526.

[3] K. Matyjaszewski, X. Zhang, J.H. Xia, Macromolecules 33 (2000) 2340.

[4] S. Angot, K.S. Murthy, D. Taton, Y. Gnanou, Macromolecules 33 (2000) 7261 .

[5] S. Angot, K.S. Murthy, D. Taton, Y. Gnanou, Macromolecules 31 (1998) 7218.

[6] D.M. Haddleton, M.C. Crossman, Macromol. Chem. Phys. 198 (1997) 871.

[7] K. Huber, W. Burchard, L.J. Fetters, Macromolecules 17 (1984) 541.

[8] M. Morton, T.D. Helminiak, S.D. Gadkary, F.J. Bueche, J. Polym. Sci. A-Polym. Chem. 57 (1962) 471.

[9] N. Hadjichristidis, A. Guyot, L.T. Fetters, Macromolecules 11 (1978) 668.

[10] S. Kanaoka, M. Sawamato, T. Higashimura, Macromolecules 24 (1991) 2309.

[11] D.J. Worsfold, J.G. Zilliox, P. Rempp, Can. J. Chem. 47 (1969) 3379.

[12] J.G. Zilliox, Macromol. Chem. 156 (1972) 121.

[13] J. Du, Y. Chen, J. Polym. Sci. A-Polym. Chem. 42 (2004) 2268.

[14] T. Fujimoto, S. Tani, K. Takano, M. Ogawa, M. Nagawawa, Macromolecules 11 (1978) 673.

[15] P. Lutz, P. Rempp, Macromol. Chem. Phys. 189 (1988) 1051.

[16] H. Shohi, M. Sawamato, T. Higashimura, Macromol. Chem. Phys. 193 (1992) 2027.

[17] S. Jacob, I. Majoros, J.P. Kennedy, Macromolecules 29 (1996) 8631

[18] M. Sawamoto, M. Kato, M. Kamigaito, T. Higashimura, Macromolecules 28 (1995) 1721.

[19] K. Matyjaszewski, T.E. Patten, J. Xia, J. Am. Chem. Soc. 119 (1997) 674.

[20] V. Percec, H.-J. Kim, B. Barboiu, Macromolecules 30 (1997) 6702 
[21] D.M. Haddleton, M.C. Crossman, K.H. Hunt, C. Topping, C. Waterson, K.G. Suddaby, Macromolecules 30 (1997) 3992.

[22] D.M. Haddleton, K. Ohno, B. Wong, J. Polym. Sci. APolym. Chem. 39 (2001) 2206.

[23] J. Ueda, M. Kamigaito, M. Sawamoto, Macromolecules 31 (1998) 6762.

[24] A. Heise, J.L. Hedrick, C.W. Frank, R.D. Miller, J. Am. Chem. Soc. 121 (1999) 8647.

[25] M. Yoo, A. Heise, J.L. Hedrick, R.D. Miller, C.W. Frank, Macromolecules 36 (2003) 268.

[26] V. Percec, B. Barboiu, T.K. Bera, M. van der Sluis, R.B. Grubbs, J.M.J. Frechet, J. Polym. Sci. A-Polym. Chem. 38 (2000) 4776.

[27] A.P. Narrainen, S. Pascual, D.M. Haddleton, J. Polym. Sci. A-Polym. Chem. 40 (2002) 439.

[28] D.M. Haddleton, R. Edmonds, A.M. Heming, E.J. Kelly, D. Kukulj, New J. Chem. 23 (1999) 477.

[29] S. Angot, D. Taton, Y. Gnanou, Macromolecules 33 (2000) 5418.

[30] K. Matyjaszewski, S. Qin, J.R. Boyce, D. Shirvanyants, S.S. Sheiko, Macromolecules 36 (2003) 1843.

[31] A. Bosman, R. Vestberg, A. Heumann, J.M.J. Frechet, C. Hawker, J. Am. Chem. Soc. 125 (2003) 715-728.

[32] R.T.A. Mayadunne, J. Jeffery, G. Moad, E. Rizzardo, Macromolecules 36 (2003) 1505-1513.

[33] M.H. Stenzel, T.P. Davis, J. Polym. Sci. A-Polym. Chem. 40 (2002) 4498-4512.

[34] J. Schmidgall, A. Hensel, Int. J. Bio. Macromol. 30 (2002) 217-225.

[35] N.A. Peppas, J.J. Sahlin, Biomaterials 17 (1996) 15531561.

[36] N.A. Peppas, P. Bures, W. Leobandung, H. Ichikawa, Euro. J. Pharm. Biopharm. 50 (2000) 27-46.

[37] A. Van Blaaderen, A. Imhof, W. Hage, A. Vrij, Langmuir 8 (1992) 1514-1517.

[38] F. Tronc, M. Li, J. Lu, M.A. Winnik, B.L. Kaul, J. Graciet, J. Polym. Sci. A-Polym. Chem. 41 (2003) 766778.

[39] R.N. Keller, H.D. Wycoff, Inorg. Synth. 2 (1947) 1. 